\title{
En monogamists bekendelse
}

Når man har været borgerligt gift så længe at sølvbrylluppet begynder at fortone sig som et kært minde, begynder man at få færten af hvad personlig identitet er for noget. Man har været gift med den samme i syvogtyve år, fem måneder, en uge og fire dage; og man og den samme er radikalt forskellige fra de to pæne unge mennesker der ser kærligt på hinanden på billedet fra bryllupsfrokosten i en sal på et provinshotel, der i mellemtiden har været radioforretning og forlængst er genopstået som bankfilial. Imellem det billede og en og den samme som sidder og kigger på det med et skævt smil, ligger tusindvis af billeder med helt nye mennesker på; børn der nu er voksne og endda et barnebarn som er blevet gammel nok til at se på billeder af sig selv og sige: "Det er mig dengang jeg var et lille barn.« Man og den samme, eller en af os, er med på mange af de billeder og vi kan genkende os fra billede til billede, vi siger: »Åh, herregud!« eller »Ja, sådan!«, men sjældent »Nej, det er løgn!« og hvis vi siger det, mener vi det ikke. Identititeten ligger i forløbet og erfaringen, ikke i personerne, og alligevel er det man og den samme som er os som er de samme.

Jeg har levet sammen med tekstanalysen endnu længere, ja fra før jeg vidste hvad den hed. Jeg vil ikke påstå at det var forelskelsen i den som fik mig til at vælge litteraturen som fag, for det var i hvert fald lige så meget forelskelsen i en præstedatter fra Vemb som gik i klasse med min storebror og tog til Århus for at læse »almindelig og sammenlignende litteraturhistorie«, noget jeg aldrig havde hørt om før. Men en af de få ting jeg husker med glæde fra min gymnasietid, var en tekstanalyse af Schillers »Das Lied von der Glocke« som jeg lavede til en tysktime. Jeg har den ikke længere og den har næppe heller været noget at gemme på, men jeg kan huske at Johansen skosede mig for nogle grammatiske bommerter og roste mig for det jeg havde fundet ud af om digtet. Og jeg husker især at det var en virkelig, intellektuel fornøjelse at lave den. Der var noget med regelmæssighed og uregelmæssighed i strofeformernes vekslen som jeg fik fat i, og som

Søren Baggesen er professor i tekstvidenskab ved Roskilde Universitetscenter. 
jeg holdt ved længe nok til at det begyndte at sige noget.

Det er det tekstanalyse handler om. Et eller andet i teksten er som det skal være, men er det på en så påfaldende måde (eller, når det er rigtig skæg, så upåfaldende at det bliver påfaldende) at man bliver opmærksom. Der tager man fat og haler, og hvis man haler længe og stærkt nok, så står man med en række af betydninger som er betydninger $\mathrm{i}$ teksten, men som kun går op for en hvis man arbejder med på dem.

Det er også det som er problemet ved tekstanalysen. Betydninger må betyde noget, de må pege på et andet som ikke er det der betyder. Eller hvis man vil hævde at betydninger bare betyder sig selv, så må man have et argument for det. Sådanne argumenter har jeg set og nogen af dem har endda været gode. Men jeg har ikke set nogen som ikke selv betyder noget, nissen flytter med og det er hans mindste kunst at flytte med til et trinhøjere niveau.

Dér er det at redaktionens dødedans begynder at sno sig over skriftsider og gennem undervisningslokaler: »nykritikken, strukturalismen, marxismen, feminismen, historicismen, psykoanalysen, postmodernismen, dekonstruktionen o.s.v.« Det er ikke kun akademisk konvention som siger at tekstanalysen ikke kan stå alene, men må have en teori at støtte sig til, tekstanalysen kan ikke stå alene fordi betydninger betyder.

Man kan udmærket lave litteraturvidenskab uden en teori. En metrisk beskrivelse (eller analyse om man vil) af Schillers digt kræver ingen teori, men bare et raffineret sæt af værktøjer for at blive i orden, stilstudier er også litteraturvidenskab. Det kan man endda komme lahgt med, selv om man nok kommer længere inden for de andre æstetiske videnskaber. Det går nemmere at sætte betydningen i parantes og hævde at Beethovens Niende eller Picassos Guernica bare er, end det går med Kafkas Slottet. Digtning er selvfølgelig også kunst, og det vil vel sige en æstetisk organisation af forefundet materiale som ikke er æstetisk i sig selv. Men selv om man forsøger sig med at hævde at digtningens materiale bare er ord som har en bestemt materialitet, så er det svært ret længe at se bort fra at de altså også har betydning. Ord er "præorganiseret« materiale på en anden måde end lyd eller form og farve.

Det gør ikke digtningen til en højere kunst end de andre, ikke engang til en som nødvendigvis må »betyde« mere end de andre i alle dette ords betydninger og betydningsnuancer. Men det gør efter min mening litteraturkritikken mere spændende at beskæftige sig med, for der er ingen vej ud. Digtningen er på en måde en mere uren kunstart end de andre, den deltager på forhånd - eller »altid allerede« som det 


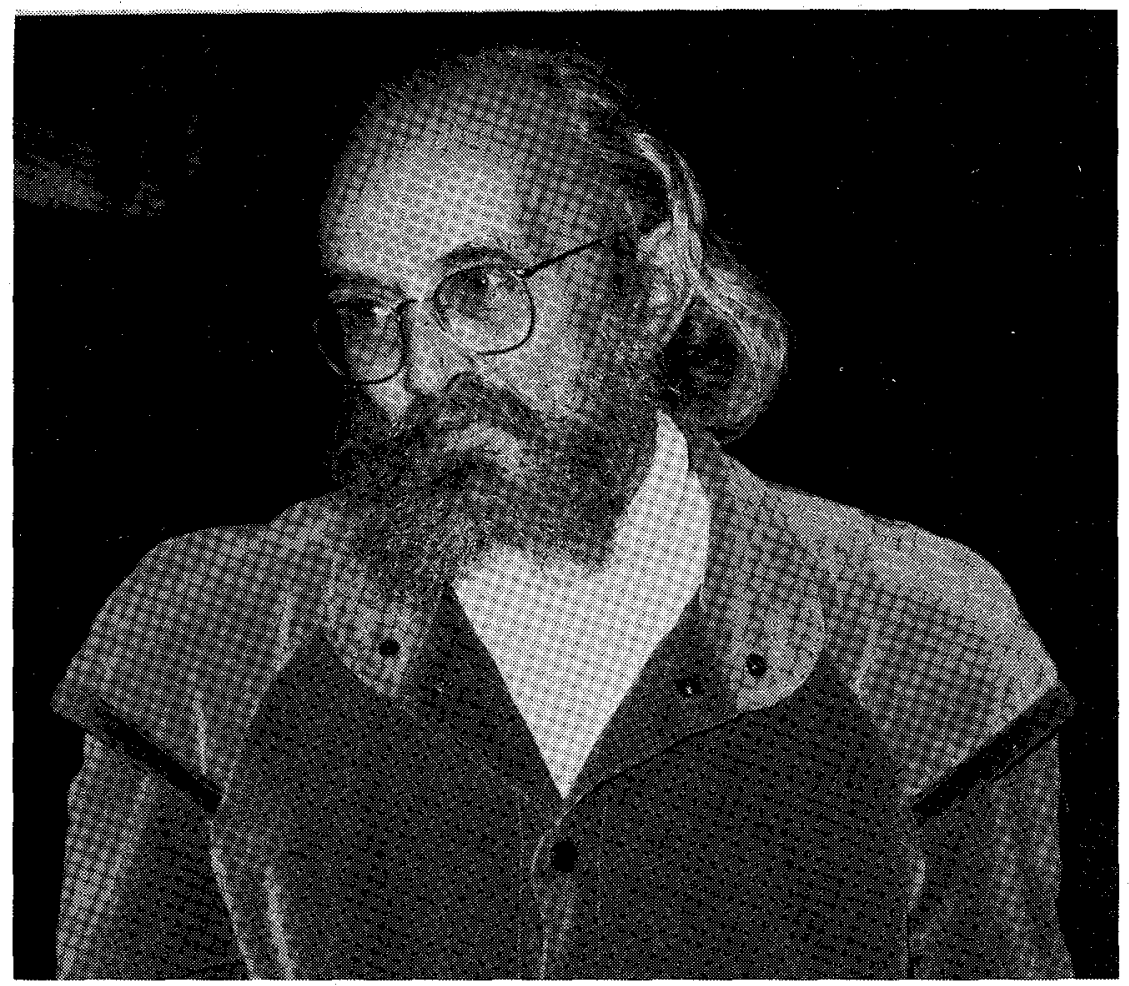

hedder med et udtryk jeg ret sent har lært, men er kommet til at holde af - $i$ noget andet end digtning, fordi den organiserer ord og dermed betydninger som bringer betydninger med sig andre steder fra.

Det er de steder dødedansen begynder. Det gælder også »nykritikken« som var den første formulerede teoridannelse jeg stødte på. Den hævdede ganske vist om sig selv at den var en teori for det autonome digtværk, men det forhindrede den ikke i at komme fra USA's »Deep South « hvor den skulle forsvare nogle konservative kulturværdier $\mathrm{i}$ 30'er-krisens hærgen. At den så blev introduceret i Danmark af et nyradikalt brushoved kan se underligt ud, men det har ingen særlig ironi i sig. Fjord introducerede nykritikken som et opbrud i en litteraturvidenskabelig institution der var så tilgroet $i$ en positivistisk teoridannelse, at det tog sig ud som den rene teoriløshed og blev præsenteret og forsvaret som sådan. Nykritikken som vi arbejdede med den $\mathrm{i}$ auditorierne i Århus dengang førte ikke sine konservative værdier med sig, men den medførte at de digteriske betydningers sammenhænge med betydningsdannelser andre steder blev synlige. Fjord indforte ikke nykritikken fordi den var ny, og da slet ikke fordi den 
ideologisk set var konservativ, han indførte den fordi den var kritisk.

Teoriernes dødedans er nok et problem for dem der laver litteraturvidenskab, men problemet er egentlig ikke litteraturvidenskabens. Teorierne er forsøg på betydningstilskrivning, eller endda meningstilskrivning til virkeligheden, og dødedansen er $\mathrm{i}$ virkeligheden déns problem. Den kommer anstigende aldeles uden mening, men forlanger uanfægtet at blive en mening til del, man kan ikke leve $i$ virkeligheden uden at den har mening. Man skal vide at der er en mening med at stå op om morgenen, ellers gør man det ikke - det er derfor man kan sove længe søndag morgen.

Teoridannelserne må forstås som forsøg på mere systematiske meningstilskrivninger til virkeligheden. Når de nu danser forbi så hastigt at det er blevet tydeligt for enhver, at det eneste man med sikkerhed kan sige når en ny dukker op $\mathrm{i}$ kæden, er at den danser mod sin død, så må man formode at det skyldes en eller anden forstyrrelse i virkeligheden. Det ikke alene kan, men må man så have en eller anden teori om, det er derfor alle de teoridannelser redaktionen remser op er kriseteorier.

Teoridannelsens nødvendighed gør at man ikke kan stå af. En konsekvens kan vel så være at danse lystigt med, men det har jeg det personligt dårligt med, jeg bliver simpelthen svimmel. Det kan muligvis også lade sig gøre at stå stille, og hævde at det der var sandt $i$ 1978 også er sandt i 1989, men det kan jeg heller ikke. Ganske vist kan det være at en ny teori kommer med påstande, så man tager sig til hovedet og siger at det kan umuligt være sandt, men den kommer i hvert fald med indvendinger imod den foruddansende, som er af en art så man må sige at dem der er godt nok noget sandt i. Redaktionen skriver ganske vist i sit enquête-brev om »modebevægelserne«, men det er en besværgelse som ikke engang redaktionen tror på, ellers havde den ikke lavet en enquête.

Jeg skylder vel så at gøre rede for hvad $\mathrm{i}$ alverdenen jeg da stiller op. Det kan jeg også sagtens: jeg forsøger at lade mig anfægte og tænke mig om på en gang. Det kan man leve med, selv om der endnu ikke er kommet nogen formuler- og holdbar teoridannelse ud af det. Et ord jeg har kendt meget længe og altid har holdt af på grund af allitterationen er »tentativt.«

Og så laver jeg altså tekstanalyser. Og så er jeg der igen for man kan ikke lave tekstanalyser uden teori. Man kan ikke påstå at det og det i teksten betyder det og det, uden at der ligger et »i virkeligheden « skjult i påstanden. Men erkendelsen af det er samtidig opdagelsen af et konvergenspunkt imellem digtningen og teorien, de er begge forsøgsvise menings- eller betydningstilskrivninger til virkeligheden. 
Det sammenfaldspunkt giver tekstanalysen et slags arkimedisk punkt. Den står medskyldigt udenfor, fordi den er en samtidig meningstilskrivning til digt-teksten og teori-teksten.

Tekstanalysen er ikke bare til at leve med, den er til at leve sammen med og det har jeg altså gjort i snart mange år. Da det her nu skal være en bekendelse må jeg hellere med et samme indrømme at der har været sidespring, både ud $\mathrm{i}$ den rene teori og (om end til skrivebordsskuffen) ud i digtningen.

Men analogien til ægteskabet går nu på noget andet, nemlig på tekstanalysens identitet. Når jeg sidder og bladrer i mine gamle tekstanalyser, og det gør jeg lige som jeg sidder og bladrer i fotoalbummene, så er det tydeligt at de er forskellige fra den ene til den anden. Det er også tydeligt at den forskellighed stammer fra, at jeg og mine tekstanalyser er med i teoriernes dødedans. Men tværs igennem dem er der også en identitet, og jeg vil vove at påstå at det er en erfaringens identitet.

Jeg vil ikke påstå, undtagen for mig selv, at mine tekstanalyser bliver bedre og bedre. Men jeg vil påstå offentligt at det kan ses på dem at de samler mere og mere op, at jeg fra den ene til den næste har været omkring flere og flere tekster (eller længere ud og dybere ned $\mathrm{i}$ dem), flere og flere teoridannelser(eller længere ud og dybere ned i dem), flere og flere betydninger og betydningsmuligheder. Det er den slags fortid som der også er en slags fremtid i.

Så jeg lever videre med tekstanalysen med samme relative sindsro som jeg lever videre i mit ægteskab. I bevidstheden om at vel kan det revne »med et brag eller en klynken«, men også i fortrøstningen til, at når det har holdt til så meget kan det holde sin tid ud. Hvad det så skal føre til i det lange løb kan man læse hos Keynes. 